\title{
EFFECTS OF PHOSPHATE LOADING AND DEPLETION ON THE RENAL EXCRETION AND REABSORPTION OF INORGANIC PHOSPHATE
}

\author{
BY DAVID D. THOMPSON ${ }^{1}$ AND HOWARD H. HIATT 2 \\ (From the National Institute of Arthritis and Metabolic Diseases, National Institutes of Health, \\ Public Health Service, U. S. Department of Health, Education and Welfare, \\ Bethesda, $M d$.)
}

(Submitted for publication August 30, 1956; accepted December 13, 1956)

A number of studies have indicated that parathyroid extract increases the renal excretion of phosphate $(1-6)$. This effect appears to result from a depression of the renal reabsorption of phosphate (6). Endogenous secretory activity of the parathyroid glands has been related to the extracellular concentration and/or the dietary intake of calcium and phosphate. Although dietary variations of these ions did not correlate consistently with $\operatorname{TmP}^{3}$ in our initial investigations (7), other workers have demonstrated an influence of diet on phosphate reabsorption. A high phosphate diet led to a diminished $\mathrm{P}$ reabsorption in normal but not in parathyroidectomized rats (8). Studies in dogs (9) and in normal human subjects (8, 10) also indicated that the level of $P$ intake influenced $\mathrm{P}$ reabsorption, but whether this effect was mediated by the parathyroid glands is not clear. In order to examine more rigorously the effects of a high $\mathrm{P}$ intake, buffered sodium phosphate solutions were administered intravenously daily for four to eight days to the normal and hypoparathyroid subjects previously described (7). Another phase of this study involved an inquiry into the mechanism by which aluminum gels produce a marked reduction in urinary $P$.

Variations in plasma levels of $\mathrm{Ca}$ and $\mathrm{P}$ often occur together. An attempt was made to separate the effects of elevation of plasma $P$ from the frequently seen simultaneous reduction in plasma $\mathrm{Ca}$.

Our data indicate that repeated daily intravenous administration of large quantities of phos-

\footnotetext{
1 Present address : Department of Physiology, Cornell University Medical College, New York 21, N. Y.

2 Present address: Department of Medicine, Harvard Medical School and Beth Israel Hospital, Boston, Mass.

${ }^{3} \mathrm{As}$ in the previous papers, the following abbreviations have been used: $\mathrm{Ca}$, calcium; $\mathrm{P}$, inorganic phosphate; $\mathrm{Tm}$, maximum renal tubular rate of transfer.
}

phate results in a reduction in renal $P$ reabsorption. This effect does not appear to depend upon an associated reduction in plasma Ca. Whether this effect is mediated via the parathyroids cannot be conclusively stated. The results indicate that aluminum gels produce their effect primarily, and perhaps solely, by effecting a reduction in plasma $P$.

\section{METHODS}

These studies were conducted on the same patients previously described, and the measurements of $\mathrm{TmP}$ were carried out by the method detailed in an earlier paper (7). In studies of the effects of intravenously administered phosphate, a buffered sodium phosphate solution, $\mathrm{pH} 7.4$, was infused over a 4 to 6 -hour period on four consecutive days. Five subjects received $75 \mathrm{mM}$ of $\mathbf{P}$ each day; two subjects, C. $H$. and D. F., received 90 and $150 \mathrm{mM} P$ per day, respectively. Two of the normal subjects, C. $H$. and E. $P$., received eight daily $P$ infusions, and on the last four days they received, in addition, infusions of $\mathrm{Ca}$. The $\mathrm{Ca}$ was administered as calcium gluconate, $15 \mathrm{mg}$. Ca per $\mathrm{kg}$. of body weight in $1,000 \mathrm{ml}$. of 5 per cent glucose in water, over a fourhour period starting several hours after the completion of the phosphate infusion. Infusions of di-sodium ethylenediamine tetraacetic acid (EDTA) were given to the four normal subjects who received intravenous phosphate. Four gm. of EDTA was administered in $1,000 \mathrm{ml}$. of 5 per cent glucose in water over a 4 to 6 -hour period daily for four consecutive days. TmP was measured prior to, and on the day following completion of the $\mathrm{P}$ or EDTA infusions.

In the studies on the effects of aluminum gels $180 \mathrm{ml}$. of basic aluminum carbonate (Basaljel(8) was administered orally each day in four divided doses, one hour after meals and at bedtime, for 6 to 21 days. Concomitantly, the subjects received a low dietary $P$ intake of 600 to $800 \mathrm{mg}$. per day. Balance studies carried out during aluminum gel administration were performed on the metabolic ward in the manner described by Deitrick, Whedon, and Shorr (11).

Chemical methods and calculations used in these studies were the same as those described in a previous communication (7). 
TABLE I

Effect of intravenous sodium phosphate on the maximal phosphate reabsorption in a normal male before $(A)$ and after (B) four daily infusions each containing $150 \mathrm{mMP}$

\begin{tabular}{|c|c|c|c|c|c|c|c|c|}
\hline \multirow{2}{*}{$\begin{array}{c}\text { Total } \\
\text { concurrent } \\
\text { time } \\
\text { min. }\end{array}$} & \multirow{2}{*}{$\begin{array}{c}\text { Urine } \\
\text { flow } \\
\text { ml./mix. }\end{array}$} & \multirow[b]{2}{*}{$\underset{m l . / m i n}{C_{\text {la }}}$} & \multirow[b]{2}{*}{$\underset{m l . / m i n .}{C_{P A B}}$} & \multirow{2}{*}{$\begin{array}{c}\text { Plasma } \\
P \\
\mu M / m l .\end{array}$} & \multirow{2}{*}{$\begin{array}{c}\text { Urine } \\
\mathbb{P} \\
\mu M / m b .\end{array}$} & \multicolumn{3}{|c|}{ Phosphate } \\
\hline & & & & & & $\begin{array}{l}\text { Filtered } \\
\boldsymbol{\mu} M / \min .\end{array}$ & $\begin{array}{l}\text { Excreted } \\
\mu M / m i n \text {. }\end{array}$ & $\begin{array}{l}\text { Reabsorbed } \\
\mu M / \min .\end{array}$ \\
\hline \multicolumn{9}{|c|}{ A. Control } \\
\hline 0 & 14.5 & $\cdot$ & & 1.01 & 1.55 & & 22 & \\
\hline 71 & \multicolumn{8}{|c|}{ Intravenous buffered sodium phosphate delivered at $0.5 \mathrm{mM} / \mathrm{min}$. } \\
\hline $\begin{array}{l}129-159 \\
159-189 \\
189-219\end{array}$ & $\begin{array}{l}12.4 \\
11.2 \\
10.1\end{array}$ & $\begin{array}{l}119 \\
110 \\
116\end{array}$ & $\begin{array}{l}500 \\
495 \\
517\end{array}$ & $\begin{array}{l}2.76 \\
3.11 \\
3.31\end{array}$ & $\begin{array}{l}17.2 \\
22.2 \\
28.2\end{array}$ & $\begin{array}{l}328 \\
342 \\
384\end{array}$ & $\begin{array}{l}214 \\
249 \\
285\end{array}$ & $\begin{array}{r}114 \\
93 \\
99\end{array}$ \\
\hline \multicolumn{9}{|c|}{ B. After 4 daily phosphate infusions $-150 \mathrm{mM} /$ day } \\
\hline $\mathbf{0}$ & 15.3 & & & 0.59 & 3.86 & & 59 & \\
\hline 45 & \multicolumn{8}{|c|}{ Phosphate infusion at $0.5 \mathrm{mM} / \mathrm{min}$. } \\
\hline $\begin{array}{l}103-135 \\
135-173 \\
173-202\end{array}$ & $\begin{array}{r}9.5 \\
9.1 \\
10.7\end{array}$ & $\begin{array}{r}99 \\
105 \\
107\end{array}$ & $\begin{array}{l}516 \\
509 \\
525\end{array}$ & $\begin{array}{l}1.97 \\
2.48 \\
2.82\end{array}$ & $\begin{array}{l}21.4 \\
28.9 \\
27.4\end{array}$ & $\begin{array}{l}195 \\
260 \\
302\end{array}$ & $\begin{array}{l}203 \\
264 \\
293\end{array}$ & $\begin{array}{r}-8 \\
-4 \\
9\end{array}$ \\
\hline
\end{tabular}

TABLE II

Summary of effects of phosphate infusions on normal and hypoparathyroid subjects

\begin{tabular}{|c|c|c|c|c|c|c|}
\hline & & \multicolumn{2}{|c|}{$\operatorname{Tm} P$} & \multirow{2}{*}{$\begin{array}{l}\text { Plasma* } \\
\mathrm{P} \\
\mu M / m l .\end{array}$} & \multirow{2}{*}{$\begin{array}{l}\text { Plasma* } \\
\text { Ca } \\
\text { mg. \% }\end{array}$} & \multirow{2}{*}{$\begin{array}{l}\text { Urine* } \\
\mathrm{P}^{\mathrm{P}} \\
\mu \mathrm{M} / \mathrm{min}\end{array}$} \\
\hline & & $\mu M / \min$. & $\%$ control & & & \\
\hline \multicolumn{7}{|l|}{ Normals } \\
\hline C. H. & $\begin{array}{l}\text { Before } \mathbf{P} \\
\text { After } \mathbf{P} \\
\text { After } \mathbf{P} \text { and Ca } \dagger\end{array}$ & $\begin{array}{l}256 \\
197 \\
168\end{array}$ & $\begin{array}{r}100 \\
77 \\
66\end{array}$ & $\begin{array}{l}1.42 \\
1.26 \\
1.08\end{array}$ & $\begin{array}{c}9.2 \\
10.20\end{array}$ & $\begin{array}{l}17 \\
32 \\
25\end{array}$ \\
\hline D. F. & $\begin{array}{l}\text { Before P } \\
\text { After P }\end{array}$ & $\begin{array}{r}102 \\
0\end{array}$ & $\begin{array}{r}100 \\
0\end{array}$ & $\begin{array}{l}1.01 \\
0.59\end{array}$ & $\begin{array}{r}9.9 \\
10.1\end{array}$ & $\begin{array}{l}22 \\
59\end{array}$ \\
\hline W. R. & $\begin{array}{l}\text { Before } \mathbf{P} \\
\text { After } \mathbf{P}\end{array}$ & $\begin{array}{r}137 \\
59\end{array}$ & $\begin{array}{r}100 \\
43\end{array}$ & $\begin{array}{l}0.97 \\
0.83\end{array}$ & $\begin{array}{r}10.30 \\
9.24\end{array}$ & $\begin{array}{l}12 \\
30\end{array}$ \\
\hline E. P. & $\begin{array}{l}\text { Before P } \\
\text { After P } \\
\text { After P and Ca } \dagger\end{array}$ & $\begin{array}{r}110 \\
70 \\
45\end{array}$ & $\begin{array}{r}100 \\
64 \\
41\end{array}$ & $\begin{array}{l}1.09 \\
1.06 \\
0.95\end{array}$ & $\begin{array}{r}11.20 \\
10.20 \\
8.86\end{array}$ & $\begin{array}{r}9 \\
24 \\
29\end{array}$ \\
\hline \multicolumn{7}{|c|}{ Hypoparathyroid } \\
\hline A. $W$. & $\begin{array}{l}\text { Before P } \\
\text { After P }\end{array}$ & $\begin{array}{l}149 \\
134\end{array}$ & $\begin{array}{r}100 \\
90\end{array}$ & $\begin{array}{l}1.37 \\
1.50\end{array}$ & $\begin{array}{l}7.10 \\
5.67\end{array}$ & $\begin{array}{r}10 \\
3\end{array}$ \\
\hline B. C. & $\begin{array}{l}\text { Before P } \\
\text { After P }\end{array}$ & $\begin{array}{l}84 \\
64\end{array}$ & $\begin{array}{r}100 \\
76\end{array}$ & $\begin{array}{l}0.91 \\
0.87\end{array}$ & $\begin{array}{l}7.6 \\
7.6\end{array}$ & $\begin{array}{l}5 \\
3\end{array}$ \\
\hline L. D. & $\begin{array}{l}\text { Before P } \\
\text { After P }\end{array}$ & $\begin{array}{r}102 \\
40\end{array}$ & $\begin{array}{r}100 \\
39\end{array}$ & $\begin{array}{l}0.79 \\
0.74\end{array}$ & $\begin{array}{l}8.89 \\
8.35\end{array}$ & $\begin{array}{l}0.8 \\
5.0\end{array}$ \\
\hline
\end{tabular}

* Specimens obtained before the first daily $P$ infusion and the day following the last $P$ infusion and prior to inulinphosphate infusions for determination of TmP.

† Four additional daily phosphate infusions were given together with 4 daily infusions of calcium gluconate (15 mg. Ca per kg.) given over a 4 to 6 hour period several hours after the phosphate infusions had been completed.

RESULTS

Effects of intravenous phosphate in normal subjects

The administration of four daily intravenous infusions of $P$ to one normal subject led to a fall in
$\mathrm{P}$ reabsorption from an average of $102 \mu \mathrm{M}$ per min. to 0 (Table $I$ ). A significant reduction in TmP was also noted in three other normal subjects (Table II). It was found that the administration of $\mathrm{Ca}$ infusions to subjects receiving $\mathrm{P}$ in- 
TABLE III

Effect of EDTA infusions on plasma concentrations, and urinary excretion of $\mathrm{Ca}$ and $P$

\begin{tabular}{|c|c|c|c|c|c|c|c|c|}
\hline & & & \multicolumn{2}{|c|}{$\begin{array}{c}\text { Plasma Ca } \\
\text { mg. \% }\end{array}$} & \multicolumn{2}{|c|}{$\begin{array}{l}\text { Plasma } P \\
\mu M / m l .\end{array}$} & \multirow{2}{*}{ 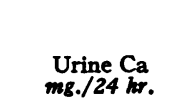 } & \multirow{2}{*}{$\begin{array}{c}\text { Urine } \\
m M / 24 \\
\text { hr. }\end{array}$} \\
\hline & & & Before & After & Before & After & & \\
\hline \multicolumn{9}{|l|}{ Normals } \\
\hline D. F. & $\begin{array}{l}3 / 3-4 \\
3 / 4-5 \\
3 / 5-6 \\
3 / 6-7\end{array}$ & $\begin{array}{l}4 \text { gm. di-Na EDTA } \\
4 \text { gm. di-Na EDTA } \\
4 \text { gm. di-Na EDTA } \\
4 \text { gm. di-Na EDTA }\end{array}$ & $\begin{array}{r}9.79 \\
8.79 \\
9.55 \\
10.35\end{array}$ & $\begin{array}{l}9.15 \\
8.85 \\
8.78 \\
9.40\end{array}$ & $\begin{array}{l}1.07 \\
0.89 \\
1.01 \\
1.12\end{array}$ & $\begin{array}{l}0.87 \\
0.69 \\
0.89 \\
0.76\end{array}$ & $\begin{array}{l}353 \\
338 \\
370 \\
280\end{array}$ & \\
\hline E. $P$. & $\begin{array}{l}4 / 10-11 \\
4 / 11-12 \\
4 / 12-13 \\
4 / 13-14 \\
4 / 14-15 \\
\text { Diet: } 135\end{array}$ & $\begin{array}{l}\text { Control } \\
4 \mathrm{gm} . \text { di-Na EDTA } \\
4 \mathrm{gm} . \text { di-Na EDTA } \\
4 \mathrm{gm} . \text { di-Na EDTA } \\
4 \mathrm{gm} . \text { di-Na EDTA } \\
5 \mathrm{mg} . \mathrm{Ca} ; 570 \mathrm{mg} . \mathrm{P} \text { daily }\end{array}$ & $\begin{array}{l}11.00 \\
10.90 \\
10.30\end{array}$ & $\begin{array}{l}9.60 \\
9.30 \\
9.20\end{array}$ & $\begin{array}{l}1.12 \\
1.02 \\
1.11 \\
1.17\end{array}$ & $\begin{array}{l}0.92 \\
0.86 \\
0.87 \\
0.72\end{array}$ & $\begin{array}{r}62 \\
356 \\
364 \\
298 \\
350\end{array}$ & $\begin{array}{l}18.2 \\
20.0 \\
20.1 \\
16.8 \\
16.3\end{array}$ \\
\hline W. R. & $\begin{array}{l}11 / 15-16 \\
11 / 16-17 \\
11 / 17-18 \\
11 / 18-19 \\
\text { Diet: } 130\end{array}$ & $\begin{array}{l}4 \mathrm{gm} . \text { di-Na EDTA } \\
4 \mathrm{gm} . \text { di-Na EDTA } \\
2 \mathrm{gm} . \text { di-Na EDTA } \\
4 \mathrm{gm} . \text { di-Na EDTA } \\
\mathrm{mg} . \mathrm{Ca} ; 1,200 \mathrm{mg} . \mathrm{P} \text { daily }\end{array}$ & $\begin{array}{l}9.58 \\
9.03\end{array}$ & $\begin{array}{l}8.57 \\
6.48\end{array}$ & 0.89 & 0.77 & $\begin{array}{l}413 \\
392 \\
189 \\
294\end{array}$ & $\begin{array}{l}46.0 \\
33.0 \\
26.0 \\
29.0\end{array}$ \\
\hline C. $\mathrm{H}$. & $\begin{array}{l}4 / 14-15 \\
4 / 15-16 \\
4 / 16-17 \\
4 / 17-18 \\
4 / 18-19\end{array}$ & $\begin{array}{l}4 \mathrm{gm} . \text { di-Na EDTA } \\
4 \mathrm{gm} \text {. di-Na EDTA } \\
4 \mathrm{gm} \text {. di-Na EDTA } \\
4 \mathrm{gm} \text {. di-Na EDTA } \\
4 \mathrm{gm} \text {. di-Na EDTA }\end{array}$ & 8.45 & 7.55 & 1.25 & 1.47 & & \\
\hline
\end{tabular}

fusions did not reverse the downward trend in TmP (Table II).

A decrease in endogenous plasma $P$ levels as a consequence of $P$ infusions was seen in the normal subjects, but there was no consistent change in plasma $\mathrm{Ca}$ (Table II). It was noted that the endogenous urinary excretion of phosphate increased in the face of a decreasing plasma $P$ level, a finding consistent with a reduced tubular $\mathrm{P}$ reabsorption.

Effects of phosphate infusions in hypoparathyroid subjects

The results of $P$ infusions in three hypoparathyroid subjects are shown in Table II. In A. W., the most severely hypoparathyroid subject, the re-

TABLE IV

Effect of EDTA on TmP in four normal subjects

\begin{tabular}{|c|c|c|c|}
\hline \multirow[b]{2}{*}{ Subject } & \multirow{2}{*}{$\begin{array}{c}\text { Control } \\
\text { TmP } \\
\mu M / m i n .\end{array}$} & \multicolumn{2}{|c|}{ After EDTA } \\
\hline & & $\mu M / \min$. & $\%$ Control \\
\hline $\begin{array}{l}\text { C. H. } \\
\text { D. F. } \\
\text { W. R. } \\
\text { E. P. }\end{array}$ & $\begin{array}{l}256 \\
102 \\
137 \\
110\end{array}$ & $\begin{array}{l}247 \\
118 \\
146 \\
112\end{array}$ & $\begin{array}{r}97 \\
116 \\
107 \\
102\end{array}$ \\
\hline
\end{tabular}

duction in $\mathrm{TmP}$ was less than that seen in normal individuals. However, the other two hypoparathyroid subjects, whose disease was considerably milder, showed reductions in $\mathrm{TmP}$ as great as those seen in the normal subjects. It can be seen that the endogenous plasma $\mathrm{P}$ levels and $\mathrm{P}$ excretion changed very little in the hypoparathyroid individuals.

\section{Effects of EDT $A$ infusions in normal subjects}

Because an elevation of plasma $\mathrm{P}$ is usually accompanied by a reduction of plasma $\mathrm{Ca}$ one must consider the possibility that the effects observed when the plasma $P$ is high may actually result from a lowered plasma $\mathrm{Ca}$. The administration of di-sodium ethylenediamine tetraacetic acid (EDTA), permitted a reduction in the circulating $\mathrm{Ca}$, particularly the ionized fraction, without a concomitant increase in plasma $P$. The effects of intravenous EDTA administration are summarized in Table III. The fall in plasma calcium seen following an infusion of EDTA actually represents a reduction in the oxalate-precipitable, and, presumably, in the ionized calcium. The urinary excretion of $\mathrm{Ca}$ is considerably elevated by the administration of EDTA. It can also be seen that 
a drop in plasma $\mathbf{P}$ usually occurred following EDTA administration. That this result is not explained by an augmented urinary $\mathrm{P}$ excretion is apparent from the excretion data on E. P. No effect of EDTA on TmP was noted in four normal subjects (Table IV).

\section{Administration of aluminum gel}

Oral administration of aluminum gel produced a reduction in fasting plasma $P$ levels and in urinary excretion of $P$ in normal individuals and in the one hypoparathyroid subject studied (Table $\mathrm{V})$. There was a profound drop in plasma $\mathrm{P}$ in the hypoparathyroid subject, A. W., on two occasions and in one normal individual, E. E. Why the latter reacted in this fashion on only one occasion is not clear; the daily dose of gel and the dietary $P$ level were similar on another occasion when a much less profound fall in plasma $P$ occurred. The fall in plasma $\mathrm{P}$ in $\mathrm{A}$. $\mathrm{W}$. as a result of aluminum gel regimen was not altered by the daily administration of as much as 400 units of parathyroid extract. Calcium, phosphorus, and nitrogen balance studies were carried out in the hypoparathyroid subject and in one normal individual before and during a course of aluminum gel. It can be seen (Figure 1 and Figure 2) that the administration of the gel resulted in an essentially P-free urine. A negative $\mathrm{P}$ balance was observed in both subjects but was much greater in the hypoparathyroid individual, and could be accounted for by an increased fecal P. Nitrogen balance was not significantly affected by the gel but calcium balance became more markedly negative in the normal subject during the period of gel administration (Table VI). The high calcium intake in the hypoparathyroid patient largely reflects supplements of calcium chloride solution which were required to prevent tetany.

\section{DISCUSSION}

Although acute elevations of plasma $P$ rarely alter $\operatorname{TmP}(7)$, repeated daily intravenous $P$ infusions result in a reduction in $\mathrm{TmP}$ in normal subjects. The decrease in endogenous plasma $P$ together with an increased endogenous $\mathrm{P}$ excretion in one subject (D. F.) are suggestive of the findings in hyperparathyroidism. It is of interest that there was no appreciable change in plasma $\mathrm{Ca}$ associated with the marked decrease in plasma $P$. Hence, if parathyroid activity were increased, one must postulate either a separation between the principle altering tubular reabsorption of $P$ and the factor which influences calcium metabolism, or a greater sensitivity of the renal tubule to the parathyroid hormone. The decrease in $\mathrm{P}$ reabsorption with $P$ infusions is in keeping with the experiments on rats and humans fed high $P$ diets (8). From our data it is not possible to be certain that the reduction in $\mathrm{TmP}$ was a result of parathyroid stimulation. Although there was little change in the $\mathrm{TmP}$ of the most severely hypoparathyroid subject, A. W., after $\mathrm{P}$ infusions, two mildly hypoparathyroid patients showed reductions of $\mathrm{TmP}$ comparable to those seen in the normal individuals. Although we are inclined to the belief that the reduction in $\mathrm{TmP}$ in these latter two subjects resulted from stimulation of existing parathyroid remnants, this conclusion cannot be definitely stated from our data.

TABLE V

\begin{tabular}{|c|c|c|c|c|}
\hline Subject & $\underset{\text { mb./day }}{\text { Dietary P }}$ & $\begin{array}{c}\text { Days on } \\
\text { aluminum } \\
\text { gel }\end{array}$ & $\begin{array}{l}\text { Plasma } P \\
\boldsymbol{\mu M / m l .}\end{array}$ & $\begin{array}{c}\text { Urine } P \\
\boldsymbol{\mu M} / \boldsymbol{m i n}\end{array}$ \\
\hline \multicolumn{5}{|l|}{ Normals } \\
\hline C. H. & $\begin{array}{r}1,800 \\
700 \\
3,000 \\
600\end{array}$ & $\begin{array}{c}\text { None } \\
7 \\
\text { None } \\
7\end{array}$ & $\begin{array}{l}1.21 \\
1.02 \\
1.19 \\
0.91\end{array}$ & $\begin{array}{r}9.0 \\
0.3 \\
31.0 \\
0.2\end{array}$ \\
\hline D. F. & $\begin{array}{r}1,000 \\
600\end{array}$ & $\begin{array}{c}\text { None } \\
10\end{array}$ & $\begin{array}{l}0.89 \\
0.62\end{array}$ & $\begin{array}{l}7.8 \\
0\end{array}$ \\
\hline J.N. & $\underset{600}{\text { Ad lib. }}$ & $\begin{array}{c}\text { None } \\
14\end{array}$ & $\begin{array}{l}1.31 \\
1.11\end{array}$ & $\begin{array}{l}8.0 \\
1.0\end{array}$ \\
\hline \multirow[t]{2}{*}{ E. E. } & $\begin{array}{r}1,800 \\
600\end{array}$ & $\begin{array}{l}\text { None } \\
11\end{array}$ & $\begin{array}{l}1.02 \\
0.86\end{array}$ & $\begin{array}{l}9.0 \\
0.1\end{array}$ \\
\hline & $\begin{array}{r}1,200 \\
600\end{array}$ & $\underset{6}{\text { None }}$ & $\begin{array}{l}1.11 \\
0.42\end{array}$ & $\begin{array}{c}14.0 \\
0\end{array}$ \\
\hline R. H. & $\begin{array}{r}3,000 \\
600 \\
600\end{array}$ & $\begin{array}{c}\text { None } \\
\text { None } \\
10\end{array}$ & $\begin{array}{l}1.13 \\
1.05 \\
0.80\end{array}$ & $\begin{array}{c}39.0 \\
3.0 \\
0\end{array}$ \\
\hline
\end{tabular}

Hypo-

parathyroid

\begin{tabular}{ccccc} 
A. W. & Ad lib. & None & 1.51 & 2.7 \\
& 600 & 10 & 0.23 & 0 \\
& 725 & None & 1.49 & 3.2 \\
& 725 & 15 & 0.16 & 0 \\
\hline
\end{tabular}




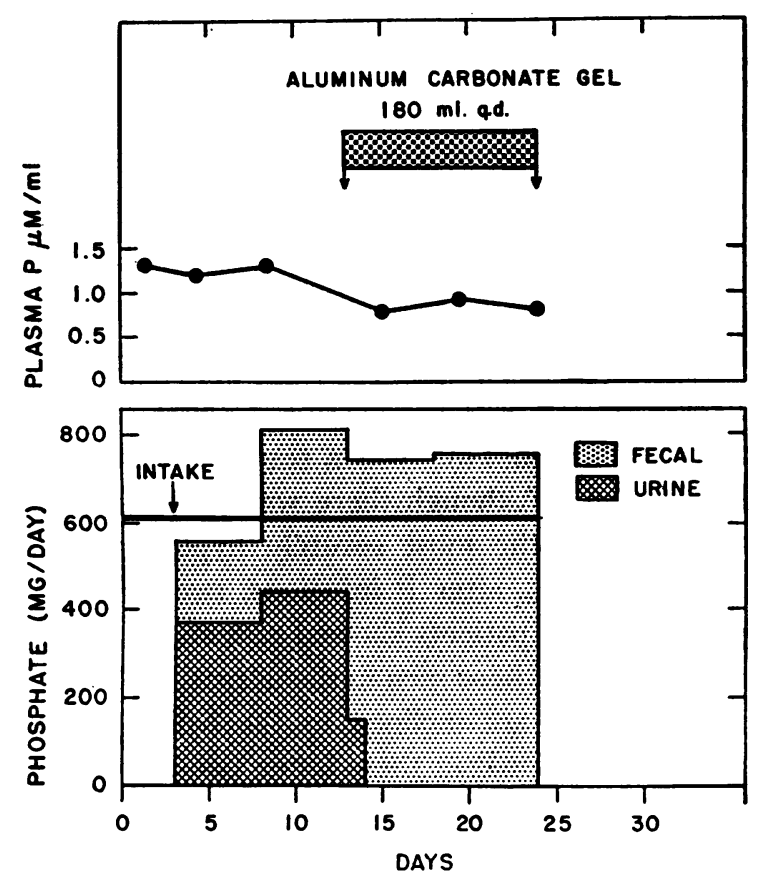

Fig. 1. The Effects of Aluminum Carbonate Gel in a Normal Subject upon Plasma P and P Balance

The reduction in $\mathrm{TmP}$ seen with phosphate infusion does not appear to be the result of the slight fall in serum calcium which occurred in most of these studies. The binding of a portion of the extracellular calcium by intravenously administered di-sodium EDTA resulted in an increase in the urinary excretion of calcium together with a reduction in the oxalate-precipitable plasma calcium. Although the decrease in plasma calcium was comparable to that seen during phosphate infusions, no reduction in $\mathrm{TmP}$ was noted after four daily EDTA infusions. Thus, it appears that the reduction in $\mathrm{TmP}$ seen with repeated administration of intravenous phosphate solutions results from a direct effect of the phosphate ion rather than from an associated decrease in the ionizable calcium. Furthermore, when calcium gluconate was infused into those patients receiving phosphate, there was no reversal of the phosphate depression of $\mathrm{TmP}$. The infusion of calcium alone has been shown to reduce phosphate excretion as a result of increased tubular phosphate reabsorption (12). This effect is probably due to inhibition of parathyroid secretion $(12,13)$. Hence, our data indicate that the effect of phosphate administration on tubular phosphate reabsorption is

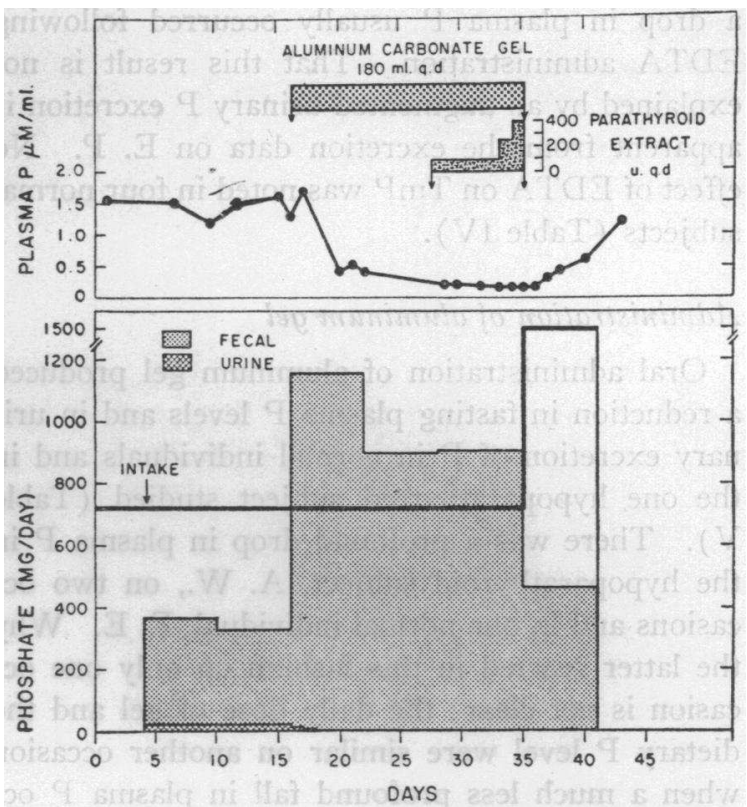

Fig. 2. The Effects of Aluminum Carbonate Gei Alone and in Combination with Parathyrom Extract in a Hypoparathyroid Subject upon Plasma P and P Balance

not altered by any parathyroid-inhibiting influence exerted by calcium.

The oral administration of aluminum gels is regularly followed by a reduction in urinary $P$ $(10,14,15)$. In normal and hypoparathyroid subjects the administration of the gel resulted in a decrease in plasma $\mathrm{P}$ as well as in urinary $\mathrm{P}$, but there was no consistent effect on TmP. Thus, it appears that the decrease in urinary $P$ which follows administration of aluminum gels is explained by a reduction in the filtered load of $P$ delivered to the renal tubules. In the face of an unchanged tubular $\mathrm{P}$ reabsorption a fall in filtered $\mathrm{P}$ leads to a decrease in $\mathrm{P}$ excretion. Conceivably, it is possible to demonstrate in the normal individual a fall in $\operatorname{TmP}$ (e.g., with repeated phosphate infusions), but not a rise, because reabsorption of $P$ by the renal tubules under normal conditions approximates their maximal capacity, and hence what approaches a "hypoparathyroid" state. This was demonstrated in a severely hypoparathyroid subject who had determinations of TmP in the untreated state and when he was receiving adequate parathyroid extract to render him "isoparathyroid." The TmP in the second situation was only slightly less than when the patient was un- 
TABLE VI

Effect of aluminum carbonate gel on calcium, phosphorus, and nitrogen balance in normal and hypoparathyroid subjects

\begin{tabular}{|c|c|c|c|c|c|c|c|c|c|c|c|c|c|}
\hline \multirow[b]{2}{*}{ Subject } & \multirow[b]{2}{*}{ Period* } & \multicolumn{4}{|c|}{ Calcium (gm./day) } & \multicolumn{4}{|c|}{ Phosphorus (sm./day) } & \multicolumn{4}{|c|}{ Nitrogen (sm./day) } \\
\hline & & Intake & Urine & Stool & Balance & Intake & Urine & Stool & $\overline{\text { Balance }}$ & Intake & Urine & Stool & Balance \\
\hline $\begin{array}{l}\text { R. H. } \\
\text { Normal }\end{array}$ & $\underset{\text { III }}{\text { II }}$ & $\begin{array}{l}0.130 \\
0.130 \\
0.130 \\
0.130\end{array}$ & $\begin{array}{l}0.102 \\
0.072 \\
0.139 \\
0.226\end{array}$ & $\begin{array}{l}0.166 \\
0.246 \\
0.291 \\
0.320\end{array}$ & $\begin{array}{l}-0.138 \\
-0.188 \\
-0.300 \\
-0.416\end{array}$ & $\begin{array}{l}0.610 \\
0.610 \\
0.610 \\
0.610\end{array}$ & $\begin{array}{l}0.349 \\
0.437 \\
0.030 \\
0.000\end{array}$ & $\begin{array}{l}0.207 \\
0.372 \\
0.710 \\
0.757\end{array}$ & $\begin{array}{l}+0.054 \\
-0.199 \\
-0.130 \\
-0.147\end{array}$ & $\begin{array}{l}8.56 \\
8.56 \\
8.56 \\
8.56\end{array}$ & $\begin{array}{l}7.72 \\
8.21 \\
6.75 \\
7.22\end{array}$ & $\begin{array}{l}1.00 \\
1.27 \\
1.10 \\
1.32\end{array}$ & $\begin{array}{l}-0.16 \\
-0.92 \\
+0.71 \\
+0.02\end{array}$ \\
\hline $\begin{array}{l}\text { A. W. } \\
\text { Hypo- } \\
\text { para- } \\
\text { thyroid }\end{array}$ & $\underset{\text { IVt }}{\text { II }}$ & $\begin{array}{l}3.406 \\
3.406 \\
3.406 \\
3.406\end{array}$ & $\begin{array}{l}0.286 \\
0.213 \\
0.158 \\
0.241\end{array}$ & $\begin{array}{l}2.983 \\
2.452 \\
3.011 \\
2.753\end{array}$ & $\begin{array}{r}+0.137 \\
+0.741 \\
+0.237 \\
+0.412\end{array}$ & $\begin{array}{l}0.725 \\
0.725 \\
0.725 \\
0.725\end{array}$ & $\begin{array}{l}0.142 \\
0.022 \\
0.003 \\
0.000\end{array}$ & $\begin{array}{l}0.399 \\
0.349 \\
1.160 \\
0.901\end{array}$ & $\begin{array}{l}+0.184 \\
+0.354 \\
-0.438 \\
-0.176\end{array}$ & $\begin{array}{l}9.10 \\
9.10 \\
9.10 \\
9.10\end{array}$ & $\begin{array}{l}8.99 \\
7.28 \\
6.43 \\
7.28\end{array}$ & $\begin{array}{l}0.76 \\
0.91 \\
1.64 \\
1.21\end{array}$ & $\begin{array}{l}-0.65 \\
+0.91 \\
+1.03 \\
+0.61\end{array}$ \\
\hline
\end{tabular}

* Each period 5 days in length.

$\dagger$ Aluminum carbonate gel $180 \mathrm{ml} . /$ day.

treated (6). If this is the case, then a slight rise in TmP might occur following the administration of aluminum gel and yet not be detectable in studies of this type.

Very striking negative phosphorus balances were produced by the administration of aluminum gel to normal and hypoparathyroid subjects. The much larger negative balance seen in the hypoparathyroid subject was accompanied by a much more profound drop in his plasma $P$. Whether this greater fecal loss of $\mathrm{P}$ and greater drop in plasma $P$ can be ascribed to the hypoparathyroidism cannot be stated. It was postulated that the profound fall in plasma $P$ in the hypoparathyroid patient on aluminum gel may have reflected an inability to mobilize skeletal stores of $P$. The inadequacy of this hypothesis, however, was demonstrated by the absence of change in the plasma $P$ level upon the administration of as much as 400 units of parathyroid extract daily.

The fall in plasma $P$ which usually followed the administration of EDTA is to be compared with the rise observed in patients who are given calcium infusions (13). This decrease in plasma $P$ was clearly not the result of any alteration in $P$ excretion but is consistent with the postulate that the level of plasma $\mathrm{Ca}$ influences the distribution of phosphate (16).

\section{CONCLUSIONS}

1. Repeated administration of intravenous buffered phosphate solutions to normal males and females resulted in pronounced reduction in TmP.

2. In one severely hypoparathyroid subject phosphate infusions produced a minimal drop in TmP while in two subjects with less marked hypoparathyroidism a reduction in $\mathrm{TmP}$ comparable to that seen in normal individuals occurred. Although it seems likely that the effect on tubular reabsorption is exerted through the parathyroids, our data are inadequate to establish this relationship.

3. The reduction in TmP appeared to be correlated with an increase in plasma $P$ rather than from any associated reduction in plasma calcium.

4. The reduction in urinary excretion of phosphate following aluminum gel administration appears to be due primarily to a reduction in endogenous plasma phosphate levels.

\section{ACKNOWLEDGMENT}

We wish to express our gratitude to Dr. G. Donald Whedon in whose laboratories the chemical determinations associated with the balance studies were carried out, and also to Misses Mary Margaret Brown and Doris Graves for their technical assistance.

\section{REFERENCES}

1. Greenwald, I., and Gross, J., The effect of the administration of a potent parathyroid extract upon the excretion of nitrogen, phosphorus, calcium, and magnesium, with some remarks on the solubility of calcium phosphate in serum and on the pathogenesis of tetany. J. Biol. Chem., 1925, 66, 217.

2. Albright, F., Bauer, W., Ropes, M., and Aub, J. C., Studies of calcium and phosphorus metabolism. IV. The effect of the parathyroid hormone. J. Clin. Invest., 1929, 7, 139.

3. Albright, F., and Ellsworth, R., Studies on the physiology of the parathyroid glands. I. Calcium 
and phosphorus studies on a case of idiopathic hypoparathyroidism. J. Clin. Invest., 1929, 7, 183.

4. Klein, R., and Gow, R. C., Interaction of parathyroid hormone and vitamin $\mathrm{D}$ on the renal excretion of phosphate. J. Clin. Endocrinol. \& Metab., 1953, 13, 271.

5. Davies, B. M. A., Gordon, A. H., and Mussett, M. V., A mouse urine phosphate essay for parathyroid hormone, with certain applications. J. Physiol., 1955, 130, 79.

6. Hiatt, H. H., and Thompson, D. D., The effects of parathyroid extract on renal function in man. J. Clin. Invest., 1957, 36, 557.

7. Thompson, D. D., and Hiatt, H. H., Renal reabsorption of phosphate in normal human subjects and in patients with parathyroid disease. J. Clin. Invest., 1957, 36, 550.

8. Crawford, J. D., Osborne, M. M., Jr., Talbot, N. B., Terry, M. L., and Morrill, M. F., The parathyroid glands and phosphorus homeostasis. J. Clin. Invest., 1950, 29, 1448.

9. Foulks, J. G., Homeostatic adjustment in the renal tubular transport of inorganic phosphate in the dog. Canad. J. Biochem. \& Physiol., 1955, 33, 638.

10. McCrory, W. W., Forman, C. W., McNamara, H., and Barnett, H. L., Renal excretion of inorganic phosphate in newborn infants. J. Clin. Invest., 1952, 31, 357.

11. Deitrick, J. E., Whedon, G. D., and Shorr, E., Effects of immobilization upon various metabolic and physiologic functions of normal men. Am. J. Med., 1948, 4, 3.

12. Hiatt, H. H., and Thompson, D. D., Some effects of intravenously administered calcium on inorganic phosphate metabolism. J. Clin. Invest., 1957, 36, 573.

13. Howard, J. E., Hopkins, T. R., and Connor, T. B., On certain physiologic responses to intravenous injection of calcium salts into normal, hyperparathyroid and hypoparathyroid persons. J. Clin. Endocrinol. \& Metab., 1953, 13, 1.

14. Fauley, G. B., Freeman, S., Ivy, A. C., Atkinson, A. J., and Wigodsky, H. S., Aluminum phosphate in the therapy of peptic ulcer. Effect of aluminum hydroxide on phosphate absorption. Arch. Int. Med., 1941, 67, 563.

15. Shorr, E., and Carter, A. C., Aluminum gels in the management of renal phosphatic calculi. J. A. M. A., 1950, 144, 1549.

16. Chen, P. S., Jr., and Neuman, W. F., Renal excretion of calcium by the dog. Am. J. Physiol., 1955, $180,623$. 